\title{
TTR
}

Traduction, terminologie, re?daction

\section{Kristen Malmkjaer, ed. Translation and Language Teaching : Language Teaching and Translation. Manchester, U.K., St. Jerome Publishing, 1998, 144 p.}

\section{Jane Koustas}

Volume 11, numéro 2, 2e semestre 1998

Psychanalyse et traduction : voies de traverse

Psychoanalysis and Translation: Passages Between and Beyond

URI : https://id.erudit.org/iderudit/037345ar

DOI : https://doi.org/10.7202/037345ar

Aller au sommaire du numéro

\section{Éditeur(s)}

Association canadienne de traductologie

ISSN

0835-8443 (imprimé)

1708-2188 (numérique)

Découvrir la revue

Citer ce compte rendu

Koustas, J. (1998). Compte rendu de [Kristen Malmkjaer, ed. Translation and Language Teaching : Language Teaching and Translation. Manchester, U.K., St Jerome Publishing, 1998, 144 p.] TTR, 11(2), 252-255.

https://doi.org/10.7202/037345ar d'utilisation que vous pouvez consulter en ligne.

https://apropos.erudit.org/fr/usagers/politique-dutilisation/ 
Kristen Malmkjaer, ed. Translation and Language Teaching : Language Teaching and Translation. Manchester, U.K., St. Jerome Publishing, 1998, 144 p.

A collection of short articles, all from Europe or the United Kingdom, this book addresses issues of interest both to language teachers and teachers of translation. As the title suggests, the relationship between language teaching and translation is explored from two perspectives : the role of language teaching in translation programs and the role of translation in language teaching. Indeed, the book is divided into three parts. The first two are dedicated to these areas and a third explores the interaction between the two.

It is worth noting, as the editor carefully points out in a valuable introduction, that the use of translation in language courses is not understood here as the antiquated and much vilified grammar-translation method. The editor offers an interesting history of the use of translation in language study suggesting not only that as it has been, and remains, a significant component in many programs (particularly in the European and British context) suggesting that one must "make the best of it" but offers support for the revival of the practice of using translation in language teaching. The first aim of the volume, and subject of the Part One, is then to discuss how translation can be used most profitably in language teaching. The second aim, the focus of the Part Two, is to encourage the incorporation of language teaching into translation programs and the third aim, to which Part Three is devoted, is to promote cooperation between teachers of language and of translation.

In Part One, the contributors discuss the kind of language study appropriate to translation programs. Rosemary MacKenzie argues that all syllabi in translation programs should include four components : linguistic 
and cultural studies and texts (tools and materials), professional service, methodology and theory. The author promotes a cooperative model of translation based on a professional model in which interaction between the translator, client and revisor is encouraged. In an article in which she recognizes both the pitfalls and advantages of translating into a second language, Joanna Weatherby recognizes that for many this is a professional necessity and identifies strategies for facilitating this task based on a functional, task-related approach to translation and proposes a sequential model of translation. Gunilla Anderman studies why translation students frequently fail to "find the right word" relating this to methods of teaching foreign language vocabulary. She explores, for example, problems related to discrepancy in lexical frequency, overextension of certain words and the poor use of dictionaries. Starting from the premise that translation in language teaching appears to be here to stay, she identifies strategies to sensitize students to the many decisions a translator must make (particularly related to word choice) and to promote text awareness.

The contributors to Part Two consider ways in which translation can be used in the language classroom. Christine Klein-Braley and Peter Franklin consider the importance of translation courses in the German university system. While professional translators are usually trained elsewhere, university graduates may find themselves in language-oriented jobs for which translation skills are an asset thus justifying translation courses in a modern language degree. The authors provide an overview of the program, which includes a German-English consolidation course, an English-German consolidation course and an optional German-English translation workshop, the goal of which is to provide broad-based language proficiency to better equip graduates for the workforce. Dennis Newson considers the use of translation exercises to measure language competence. While he presents arguments against using translation in language teaching, the author provides suggestions for improving student performance on transiation tests in this context. He proposes better text selection, simultaneous translation target language structure oriented practice, and contextualized drills. Richard Stibbard's study is based on his experience in Hong-Kong where conversational speech consists for many of a fluid mix of Cantonese and English rendering code-switching a natural activity. Stibbard thus justifies the use of translation in the English as a Foreign Language classroom and encourages the 
development of this as a useful fifth language skill. He suggests activities based on oral practice and contrastive exercises which consider cultural differences. Marie Källkvist studies lexical errors by comparing students' compositions and translation, frequently used as tests of proficiency. She focuses on the use of nouns, lexical verbs and adjectives in the written production of university-level Swedish learners of English by comparing the frequency and the types of errors. After outlining the testing procedure and the method of evaluation, she concludes that different proportions and different types of lexical errors are induced by compositions and translations.

The final chapter, entitled "At the Interface" includes four articles which consider the differences and similarities between the teaching of language and of translation. Adelina Ivanova attempts to define the knowledge and skill requirements of the translation task and relates her conclusions to experimental findings on language learners' translation skills. She then discusses a translation module which addresses some of the aspects of the language learners' translation processing. In an article in which she addresses the problem of teaching translation students what they did not learn in their language classes, Jean Vienne points out that while many language specialists do not become translators, they enter professions in which a basic understanding of translation is an asset. After briefly discussing the notion of translational competence, the author outlines strategies for teaching professional translation stressing the need for situational analysis and resource research and exploitation, activities which would be beneficial to the language learner as well. Christina Schaffner begins by considering the Institute for Linguists' (located in the U.K.) examination for the Diploma in Translation. Concluding that this test measures linguistic competence rather than the ability to translate, Schäffner identifies strategies for developing translation competence as well as ways to measure this. Andrew Chesterman studies communication and learning strategies and their relationship to translation strategies. The author concludes that while communication strategies aim to solve means problems and learning strategies choice problems, translation strategies are used for goal problems thus justifying an action-theory approach.

The contributors clearly illustrate knowledge of translation teaching and a deep awareness of the problems involved in combining 
language teaching and translation. Indeed, experienced teachers and practitioners will recognize familiar problems and find little to disagree with in these short, (most papers are under ten pages), well-documented studies. The bibliographies are valuable, although there is a heavy reliance on some authors, such as P. Sewell. While well-written for the most part, the articles, some of which are quite anecdotal, are too short to provide more than a brief look at the fundamental issues suggesting that the volume is comprised of conference papers which merely highlight important questions or deal briefly with concrete examples from the presenter's experience. Because of the limited sample size, the conclusions of some of the data-based articles are questionable. This is not to diminish the value of this slim collection which would be a useful tool to those establishing translation programs and courses : indeed, the references alone are of considerable interest. Experienced translators and teachers of translation may find interesting as well this more formal discussion of topical issues, regularly occurring problems and possible solutions. It is worth noting that the fundamental questions dealt with, however briefly, are indeed of great importance.

\author{
Jane Koustas \\ Brock University
}

